\title{
Genetic characterization of Curraleiro Pé-Duro bovine breed from a conservation herd of Brazilian semiarid
}

\author{
E. Silva Filho', M.H. Silva ${ }^{1}$, J.E.G. Campelo ${ }^{2}$, M.R. DeRosia ${ }^{3}$, \\ L.M.L. Pinheiro ${ }^{4}$ and M.J.O. Almeida ${ }^{5}$ \\ ${ }^{1}$ Instituto de Ciências Agrárias, Universidade Federal Rural da Amazônia, \\ Belém, PA, Brasil \\ ${ }^{2}$ Departamento de Zootecnia, Universidade Federal do Piauí, \\ Campus Universitário Ministro Petrônio Portela, Teresina, PI, Brasil \\ ${ }^{3}$ Colorado Renewable Energy Society, Lakewood, CO, USA \\ ${ }^{4}$ Departmento de Ciências Naturais, Universidade Federal do Pará, \\ Breves, PA, Brasil \\ ${ }^{5}$ Embrapa Meio-Norte, Teresina, PI, Brasil \\ Corresponding author: E.S. Filho \\ E-mail: silva.filho@ufra.edu.br
}

Genet. Mol. Res. 13 (1): 2149-2154 (2014)

Received February 4, 2013

Accepted August 27, 2013

Published March 24, 2014

DOI http://dx.doi.org/10.4238/2014.March.24.22

\begin{abstract}
Curraleiro Pé-Duro is a rustic bovine taurine breed found in Northeast of Brazil; this breed has decreased its production potentially in order to adapt to the region environment conditions. Consequently, it is under risk of extinction and is maintained at a preservation center in Piauí State, Brazil, as a source of genetic material adapted to local conditions. We analyzed genetic variability of this breed using microsatellite markers. Sixty animals were genotyped using 11 microsatellite loci normally used for paternity tests in bovines. The observed number of alleles ranged from 5 to 9 , and the effective number of alleles ranged from 2.01 to 4.64 . The Shannon index ranged from 0.949 to 1.669 . The expected heterozygosity ranged from 0.510 to 0.798 . Polymorphism
\end{abstract}


information content values ranged from 0.453 to 0.751 . Divergence from Hardy-Weinberg equilibrium was significant and the mean $F_{\text {IS }}$ value was 0.010 . We conclude that this breed still has some genetic diversity, but with evident risk due to genetic drift caused by current breeding management. It will be necessary to insert animals from other herds to obtain the desired level of genetic variability in this breed remnant.

Key words: Creole; Genetic diversity; STRs; Heterozygosis

\section{INTRODUCTION}

Brazil has the world's second biggest cattle herd, behind only India, according to data from the Food and Agriculture Organization of the United Nations (FAO, 2007). Brazil is also the second biggest in cattle meat production, with an annual per capita consumption of around $34.7 \mathrm{~kg}$ per inhabitant. Additionally, it is the biggest cattle meat exporter in the world. The official number of cattle registered in Brazil by "Pesquisa da Pecuária Municipal" of the Brazilian Institute of Geography and Statistics (IBGE, 2010) is 209.5 million animals. This number includes animals used for both meat and dairy production.

Curraleiro Pé-Duro is a typical cattle breed in the semiarid region of Northeast Brazil. It comes from the breeding of Alantejana and Galega breeds. These were introduced in Brazil by Portuguese colonials and Spanish animals from Prata colony (Athanassof, 1958). They are small-size animals, with robust body that comes from the expression of genes that provide heat resistance as well as resistance to drought and starvation. They also show great immunologic response. These genetic quality traits have been acquired as an adaptive response to the local environment. They qualify Curraleiro Pé-Duro breed as a great potential genetic resource for use in genetic improvement programs in Brazilian cattle. However, the price paid for good adaptation to the environment and for animal production in Brazil, is the substitution of this local breed by exotic breeds, especially the zebuine breeds (Mariante and Egito, 2002).

Although some Brazilian breeds are known by different names in different geographic regions, they have similar phenotype traits. This makes their identity doubtful as a breed group. These populations may or may not be genetically similar, even belonging to the same breed, as a consequence of geographic isolation and adaptation to ecologic niches. Therefore, they might have accumulated different alleles by breed genetic drift (Egito et al., 2002). Hence, genetic characterization is an excellent tool to identify these distinct genetic groups.

The aim of this study was to estimate the genetic variability, by microsatellite markers, of Curraleiro Pé-Duro cattle from the herd at the Conservation Center of the Breed kept at the Experimental Farm Octavio Domingues, located in São João do Piauí, Piauí State, Brazil, and supervised by Empresa Brasileira de Pesquisas Agropecuárias (Embrapa Meio Norte).

\section{MATERIAL AND METHODS}

\section{Sample and genotyping}

A total of 60 animals were randomly selected, and a $5-\mathrm{mL}$ blood sample was collected from the jugular vein using Vacutainer tubes. These samples were used for DNA extraction 
by the phenol/chloroform/isoamyl alcohol method in $1.5-\mathrm{mL}$ tubes following the protocol described by Sambrook et al. (1989).

A set of eleven microsatellite loci recommended by the International Society of Animal Genetics (ISAG) were selected: BM1818, BM1824, BM2113, ETH10, ETH225, ETH3, INRA23, SPS115, TGLA122, TGLA126, and TGLA227. Polymerase chain reaction (PCR) was performed in multiplex in a final volume of $15 \mu \mathrm{L}$, according to the following conditions: 1X STR 10X buffer (Promega, Brazil); $1.5 \mathrm{mM} \mathrm{MgCl}_{2}$ (Promega, Brazil); $1.4 \mathrm{pM}$ of each forward primer labeled with one of the fluorochromes FAM, HEX or TAMRA and $1.4 \mathrm{pM}$ of each reverse primer not labeled; 0.5 U Taq DNA Polymerase Platinum ${ }^{\circledR}$ (Life Technology, Brazil) and 50-100 ng genomic DNA.

Reactions were performed in a PCR Mastercycler (Eppendorf, Germany). PCR conditions were as follows: initial heating at $94^{\circ} \mathrm{C}, 4 \mathrm{~min} ; 30$ cycles of $94^{\circ} \mathrm{C}$ for $1 \mathrm{~min}, 58^{\circ} \mathrm{C}$ for 1 min and $72^{\circ} \mathrm{C}$ for $1 \mathrm{~min}$; ending with extension at $72^{\circ} \mathrm{C}$ for $4 \mathrm{~min}$. PCR products were separated in an ABI 3100 automated DNA sequencer (Applied Biosystems), and fragments were analyzed by Genotyper (Applied Biosystems).

\section{Data analyses}

The POPGENE 1.32 software (Yeh et al., 1999) was used to determine the frequencies of each locus, as well as some indices of diversity, including number of observed alleles $\left(N_{\mathrm{A}}\right)$ per locus; number of effective alleles $\left(N_{\mathrm{E}}\right)$ and Shannon index $(\mathrm{SI})$. The expected heterozygosity $\left(H_{\mathrm{E}}\right)$ for each locus was estimated according to Nei and Roychoudhury (1974). The estimation of polymorphic information content (PIC) was obtained according to Botstein et al. (1980). An exact test was used to determine possible deviation from Hardy-Weinberg equilibrium (HWE), and the existence of random associations of the genotypes by using the Markov chain method, and the coefficient of inbreeding $\left(F_{\text {IS }}\right)$ within the population was also determined using the GENEPOP 3.1d software (Raymond and Rousset, 1995).

\section{RESULTS}

A total of 71 different alleles were found for the eleven loci analyzed in the Curraleiro Pé-Duro breed. The least polymorphic loci were TGLA126, ETH10 and BM1824 with 5 alleles and the most polymorphic locus was SPS115 with 9 alleles. The average $N_{\mathrm{A}}$ was $6.45 \pm 1.21$. The loci with the lowest proportion of $N_{\mathrm{E}}$ were INRA23 and TGLA122 with 29.8 and $66.3 \%$, respectively (Table 1 ).

The SI varied from 0.949 to 1.669 (TGLA126 and TGLA122 loci, respectively) and averaged $1.324 \pm 0.218$. $H_{\mathrm{E}}$ ranged between 0.510 and 0.798 (lowest and highest respectively, TGLA126 and TGLA122) with an average of $0.675 \pm 0.091$. The two loci TGLA126 and INRA23 showed low PIC, that is, below 0.500. PIC of the other nine loci was higher than 0.500 and the TGLA122 locus had the highest PIC value (0.751) (Table 2). $F_{\text {IS }}$ was not significantly different from zero $(\mathrm{P} \geq 0.05)$; however, the majority of the loci were negative, with the final average being positive (0.010), thereby indicating a small degree of inbreeding (Table 2).

The probabilities for HWE were also not significant $(\mathrm{P} \geq 0.05)$ for the majority of the 
loci. ETH225, ETH3 and SPS122 loci were, however, significant for HWE $(\mathrm{P} \leq 0.05)$. When all the loci were evaluated together, the results showed deviation from HWE $(\mathrm{P} \leq 0.05)$ (Table 2).

Table 1. Alleles and their respective frequencies in brackets. Number of observed alleles $\left(N_{\mathrm{A}}\right)$ and effective alleles in brackets $\left(N_{\mathrm{E}}\right)$ for all the loci found in Curraleiro Pé-Duro breed.

\begin{tabular}{|c|c|c|c|c|c|c|c|c|c|c|}
\hline BM1818 & BM1824 & BM2113 & ETH10 & ETH225 & ETH3 & INRA23 & SPS115 & TGLA122 & TGLA126 & TGLA227 \\
\hline $260(0.11)$ & $178(0.09)$ & $133(0.26)$ & $210(0.10)$ & $140(0.29)$ & $100(0.01)$ & $198(0.13)$ & $150(0.01)$ & $141(0.04)$ & $115(0.67)$ & $77(0.37)$ \\
\hline $262(0.34)$ & $180(0.43)$ & $135(0.51)$ & $212(0.04)$ & $144(0.42)$ & $106(0.01)$ & $202(0.02)$ & $156(0.01)$ & $145(0.03)$ & $117(0.22)$ & $79(0.03)$ \\
\hline $264(0.14)$ & $182(0.30)$ & $137(0.16)$ & $214(0.23)$ & $146(0.01)$ & $112(0.08)$ & $206(0.15)$ & $246(0.02)$ & $151(0.05)$ & $119(0.03)$ & $81(0.13)$ \\
\hline $266(0.29)$ & $188(0.17)$ & $139(0.04)$ & $220(0.47)$ & $148(0.06)$ & $114(0.50)$ & $208(0.02)$ & $248(0.51)$ & $153(0.24)$ & $123(0.01)$ & $83(0.03)$ \\
\hline $268(0.03)$ & $192(0.01)$ & $143(0.01)$ & $222(0.17)$ & $150(0.01)$ & $120(0.17)$ & $210(0.01)$ & $250(0.02)$ & $157(0.12)$ & $125(0.08)$ & $87(0.34)$ \\
\hline $270(0.03)$ & & $145(0.03)$ & & $160(0.22)$ & $122(0.22)$ & $214(0.67)$ & $252(0.09)$ & $161(0.28)$ & & $89(0.06)$ \\
\hline $272(0.06)$ & & & & & $126(0.03)$ & $216(0.01)$ & $\begin{array}{l}256(0.33) \\
257(0.01) \\
258(0.02)\end{array}$ & $167(0.24)$ & & $91(0.06)$ \\
\hline $\begin{array}{l}N_{\mathrm{A}}\left(N_{\mathrm{E}}\right) \\
7(4.19)\end{array}$ & $\begin{array}{l}N_{\mathrm{A}}\left(N_{\mathrm{E}}\right) \\
5(3.18)\end{array}$ & $\begin{array}{l}N_{\mathrm{A}}\left(N_{\mathrm{E}}\right) \\
6(2.84)\end{array}$ & $\begin{array}{l}N_{\mathrm{A}}\left(N_{\mathrm{E}}\right) \\
5(3.25)\end{array}$ & $\begin{array}{l}N_{\mathrm{A}}\left(N_{\mathrm{E}}\right) \\
6(3.23)\end{array}$ & $\begin{array}{l}N_{\mathrm{A}}\left(N_{\mathrm{E}}\right) \\
7(3.02)\end{array}$ & $\begin{array}{l}N_{\mathrm{A}}\left(N_{\mathrm{E}}\right) \\
7(2.06)\end{array}$ & $\begin{array}{l}N_{\mathrm{A}}\left(N_{\mathrm{E}}\right) \\
9(2.68)\end{array}$ & $\begin{array}{l}N_{\mathrm{A}}\left(N_{\mathrm{E}}\right) \\
7(4.64)\end{array}$ & $\begin{array}{l}N_{\mathrm{A}}\left(N_{\mathrm{E}}\right) \\
5(2.01)\end{array}$ & $\begin{array}{l}N_{\mathrm{A}}\left(N_{\mathrm{E}}\right) \\
7(3.64)\end{array}$ \\
\hline
\end{tabular}

Table 2. Results of diversity parameters analyzed as Shannon index (SI), expected heterozygosis $\left(H_{\mathrm{E}}\right)$, polymorphic information content (PIC), heterozygosis deficit $\left(F_{\mathrm{IS}}\right)$ and probability for Hardy-Weinberg equilibrium. (P-HW).

\begin{tabular}{|c|c|c|c|c|c|}
\hline Loci & SI & $H_{\mathrm{E}}$ & PIC & $F_{\text {IS }}$ & P-WH \\
\hline BM1818 & 1.615 & 0.774 & 0.726 & -0.043 & 0.860 \\
\hline BM1824 & 1.281 & 0.698 & 0.632 & 0.085 & 0.521 \\
\hline BM2113 & 1.250 & 0.658 & 0.595 & 0.056 & 0.779 \\
\hline ETH10 & 1.353 & 0.704 & 0.648 & 0.021 & 0.851 \\
\hline ETH225 & 1.301 & 0.702 & 0.635 & 0.188 & 0.007 \\
\hline ЕTH3 & 1.343 & 0.680 & 0.625 & 0.211 & 0.008 \\
\hline INRA23 & 1.040 & 0.523 & 0.477 & -0.061 & 0.626 \\
\hline SPS115 & 1.253 & 0.637 & 0.565 & -0.242 & 0.000 \\
\hline TGLA122 & 1.669 & 0.798 & 0.751 & -0.011 & 0.806 \\
\hline TGLA126 & 0.949 & 0.510 & 0.453 & -0.088 & 0.794 \\
\hline TGLA227 & 1.511 & 0.737 & 0.682 & -0.003 & 0.735 \\
\hline Means & 1.324 & 0.675 & 0.617 & 0.010 & $\mathrm{P}=0.001$ \\
\hline SD & 0.218 & 0.091 & 0.092 & 0.127 & \\
\hline
\end{tabular}

General probability in bold.

\section{DISCUSSION}

Comparing the $N_{\mathrm{A}}$ and $N_{\mathrm{E}}$ parameters determined in Curraleiro Pé-Duro breed with the results of other breeds, it is worth highlighting that Curraleiro Pé-Duro breed was more polymorphic, according to the majority of the loci, compared to breeds such as Haryana and Hissar studied by Rehman and Khan (2009) using the same markers as those in this study.

In the four genetic markers that were common to this study, Curraleiro Pé-Duro breed was less polymorphic than the Quinchuan breed (Sun et al., 2007), in both $N_{\mathrm{A}}$ and $N_{\mathrm{E}}$. Also, Creole breed had three markers in common with this study (Steigleder et al., 2004), and Nellore breed studied by Carneiro et al. (2007) had 10 microsatellite loci in common. The taurine and zebuine groups were studied in Brazil by Egito et al. (2007), who measured only $N_{\mathrm{A}}$ in nine genetic markers in common.

Comparisons of $H_{\mathrm{E}}$ and PIC of Curraleiro Pé-Duro breed in relation to other breeds 
that were studied using some microsatellite loci in common with this study showed similar findings in Creole (Steigleder et al., 2004) and Grey (Teneva et al., 2005) breeds. An exception was found for the TGLA122 locus, which showed a higher PIC in Curraleiro Pé-Duro.

When compared with Haryana and Hissar breeds (Rehman and Khan, 2009), Curraleiro Pé-Duro breed showed $27 \%$ of loci with higher values for $H_{\mathrm{E}}$ for all eleven loci studied. Regarding the Kangayam (Karthickeyan et al., 2009) and Simmental (Choroszy et al., 2006) breeds, Curraleiro Pé-Duro had higher numbers in $60 \%$ of the loci for both $H_{\mathrm{E}}$ and PIC and $22 \%$ higher for $H_{\mathrm{E}}$ and $33 \%$ for PIC, respectively. Curraleiro Pé-Duro compared to taurine (Egito et al., 2007) had lower PIC values for all loci, and SPS115 locus was the only one that showed higher numbers for heterozygosity. The same was observed in one zebuine group (Egito et al., 2007), with Curraleiro Pé-Duro breed displaying lower values for the majority of the loci in the heterozygosity and PIC parameters. With regard to the BM2113, INRA23 and TGLA126 loci, Curraleiro Pé-Duro also had lower numbers for heterozygosity when compared to other breeds, and the INRA23, SPS115 and TGLA126 loci showed lower PIC values in all the breeds compared.

The average value for $F_{\text {IS }}$ was lower than that found for the same loci in the Haryana and Hissar (Rehman and Khan, 2009), Hallikar (Shekar et al., 2011) and Brown Swiss (Dalvit et al., 2008) breeds, as well as in the taurine and zebuine groups raised in Brazil (Egito et al., 2007). HWE detected in Curraleiro Pé-Duro breed was possibly related to genetic drift, due to inbreeding. However, the effect of artificial selection on the loci has also been pointed out by Rehman and Khan (2009) explaining a similar situation, besides the presence of many null alleles per locus in this analysis. However, Curraleiro Pé-Duro breed is losing genetic variability by inbreeding, and because it is a conservation herd, there is an urgent need to increase it by efficient genetic and reproductive management with better leveraging of outbred bulls and even introduction of animals from other herds.

\section{ACKNOWLEDGMENTS}

We are grateful to EMBRAPA Meio Norte for permission to obtain samples from the Conservation Center of Curraleiro Pé-Duro Breed.

\section{REFERENCES}

Athanassof N (1958). Raças de Gado Comum Sem Aptidões Especializadas. In: Manual do Criador de Bovinos (Athanassof N, ed.). Melhoramentos, São Paulo, 191-214.

Botstein D, White RL, Skolnick M and Davis RW (1980). Construction of a genetic linkage map in man using restriction fragment length polymorphisms. Am. J. Hum. Genet. 32: 314-331.

Carneiro TX, Gonçalves EC, Schneider MPC and Silva A (2007). Diversidade genética e eficiência de DNA microssatélites para o controle genealógico da raça Nellore. Arq. Bras. Med. Vet. Zootec. 59: 1257-1262.

Choroszy B, Janik A, Choroszy Z and Zbek T (2006). Polymorphism of selected microsatellite DNA sequences in Simmental cattle chosen for identification of QTLs for meat traits. Anim. Sci. Pap. Rep. 24: 71-77.

Dalvit C, De Marchi M, Dal ZR, Zanetti E, et al. (2008). Genetic characterization of the Burlina cattle breed using microsatellites markers. J. Anim. Breed Genet. 125: 137-144.

Egito AA, Mariante AS and Albuquerque MSM (2002). Programa brasileiro de conservação de recursos genéticos animais. Arch. Zootec. 51: 39-52.

Egito AA, Paiva SR, Albuquerque MDSM and Mariante AS (2007). Microsatellite based genetic diversity and relationships among ten Creole and commercial cattle breeds raised in Brazil. BMC Genet. 8: 1-14.

FAO (2007). The State of the World's Animal Genetic Resources for Food and Agriculture. FAO, Rome. 
IBGE, Instituto Brasileiro de Geografia e Estatística (2010). Produção da Pecuária Municipal. Rio de Janeiro.

Karthickeyan SMK, Sivaselvam SN, Selvam R and Thangaraju P (2009). Microsatellite analysis of Kangayam cattle (Bos indicus) of Tamilnadu. Indian. J. Sci. Technol. 2: 38-40.

Mariante AS and Egito AA (2002). Animal genetic resources in Brazil: result of five centuries of natural selection. Theriogenology 57: 223-235.

Nei M and Roychoudhury AK (1974). Sampling variances of heterozygosity and genetic distance. Genetics 76: 379-390.

Raymond M and Rousset F (1995). Genepop (Version-1.2) - Population-Genetics Software for Exact Tests and Ecumenicism. J. Hered. 86: 248-249.

Rehman MS and Khan MS (2009). Genetic diversity of hariana and hissar cattle from Pakistan using microsatellite analysis. Pak. Vet. J. 29: 67-71.

Sambrook J, Fritsch EF and Maniatis T (1989). Molecular Cloning. In: A Laboratory Manual. 2nd edn. Cold Spring Harbor Laboratory Press, New York.

Shekar MC, Kumari JU, Karthickeyan SMK and Muthezhilan R (2011). Assessment of with-in breed diversity in Hallikar cattle (Bos indicus) through microsatellite markers. Idian. J. Sci. Technol. 4: 895-898.

Steigleder CS, Almeida EA and Weimer TA (2004). Genetic diversity of a Brazilian creole cattle based on fourteen microsatellite loci. Arch. Zootec. 53: 3-11.

Sun W, Chen H, Lei C, Lei X, et al. (2007). Study on population genetic characteristics of Qinchuan cows using microsatellite markers. J. Genet. Genomics 34: 17-25.

Teneva A, Todorovska E, Tyufekchiev N and Kozelov L (2005). Molecular characterization of Bulgarian livestock genetic resources 1. Genetic diversity in Bulgarian grey cattle as revealed by microsatellite markers. Biotechnol. Anim. Husb. 21: 35-41.

Yeh F, Yang C and Boyle T (1999). POPGENE Version 1.32 Microsoft Window-Based Freeware for Population Genetic Analysis. University of Alberta, Edmonton. 